\title{
Argyreia sharadchandrajii (Convolvulaceae), a new species from the Western Ghats, India
}

\author{
Lawand P.R. \& V.B. Shimpale* \\ Department of Botany, The New College, Kolhapur, Maharashtra - 416 012, India \\ *E-mail: vshimpale@gmail.com
}

\begin{abstract}
Argyreia sharadchandrajii Lawand \& Shimpale, a new species from the Western Ghats of Maharashtra, India is described and illustrated. Argyreia sharadchandrajii is morphologically similar to A. pilosa Wight \& Arn. but differs in habit, shape of leaves and bracts, indumentum and size of peduncle, sepal and berries. Notes on taxonomy and conservation status are provided.
\end{abstract}

Keywords: Asia, Ipomoeae, Maharashtra, Morning glory, Taxonomy.

\section{Introduction}

Argyreia Lour. is one of the speciose genera within the morning glory family Convolvulaceae. Until recently, the species number in Argyreia was the subject of uncertainty but a comprehensive nomenclatural review by Staples and Traiperm (2017) has given a convincing number of 135 species throughout the world. The genus is native to continental Asia with almost all taxa distributed in the tropical, sub-tropical regions of Southeast Asia, China and the Indian subcontinent. The concept of the genus has undergone several taxonomic alterations. Lettsomia Roxb. was separated from Argyreia by Roxburgh (1824) based on the presence of a bilocular ovary, and was later remerged with Argyreia by Choisy (1834). However, he established a new genus Moorcroftia Choisy (Choisy, 1834) that too was later sunk in Argyreia by Van Ooststroom (1943). A

Received: 13.03.2020; Revised \& Accepted: 11.01.2021

Published Online: 31.03 .2021 monographic study of the genus has not been attempted, although some comprehensive floristic treatments by Ooststroom and Hoogland (1953), Austin (1980), Fang and Staples (1995), Staples and Traiperm (2010) are available. In India, the genus is represented by $c .40$ species of which 17 are endemic (Lawand, 2019; Lawand et al., 2019). Except Clarke's (1883) account of the genus in The Flora of British India, no complete treatment exists for Indian Argyreia. Since then, a few novelties were described from India: A. boseana Santapau \& V.Patel from the Western Ghats (Santapau \& Patel, 1958), A. arakuensis N.P.Balakr. from Araku valley (Balakrishnan, 1961), A. srinivasanii Subba Rao \& Kumari from the Eastern Ghats (Kumari et al., 2003) and A. lakshminarasimhanii S.Shalini, Sujana, Arisdason \& D.Maity from the southern Western Ghats (Shalini et al., 2020). Most taxonomic data pertaining to Indian Argyreia is scattered in regional floras.

The generic circumscription of Argyreia along with Ipomoea L. has been discussed early on by many authors (Clarke, 1883; Cooke, 1908; Ooststroom \& Hoogland, 1953). A recent molecular phylogenetic study (Muñoz-Rodríguez et al., 2019) suggests that the traditional genus Argyreia should be merged in Ipomoea. However, after critical analysis of the literature, we have an opinion that it is better to maintain their identity as a separate entity. At the generic level Argyreia can easily be distinguished from its allied genera by an array of characters such as their habit as mostly semi-woody lianas, corolla with hairy midpetaline bands, flowers 
subtended with well-developed bracts and indehiscent berry. Both genera can be separated on cytological evidence. Sampathkumar and Ayyangar (1981) have shown that chromosomes in Argyreia are longer $(5-8.5 \mu \mathrm{m})$ while those in Ipomoea are shorter $(2-4 \mu \mathrm{m})$. Notably, the genus Argyreia is distributed in Asia while Ipomoea occurs worldwide (Mabberley, 2018).

During botanical excursions in 2016, as part of a revisionary study of the genus Argyreia in India, the authors found a specimen of Argyreia. The first impression was that it represented a geographical variation of $A$. pilosa Wight \& Arn., an endemic species of Peninsular India. The proposed species was observed for three consecutive years to confirm that it displays constant morphological characters. On a careful literature survey, studying characters of taxonomic significance, type and protologue of its morphologically allied species, $A$. pilosa, it was confirmed that our collection represents a new species of Argyreia, which is described and illustrated here.

\section{Taxonomic treatment}

Argyreia sharadchandrajii Lawand \& Shimpale, sp. nov.

Figs. 1, 2 \& 3(e-h)

Similar to $A$. pilosa but can be distinguished by its prostrate habit, terete petioles, widely ovate to orbicular leaves, white sericeous indumentum on abaxial leaf surface, short peduncles, oblong or lance-ovate bracts, unequal sepals and larger berries (2-2.5 $\mathrm{cm}$ across). The differences between the two species are presented in Table 1 and pictorially represented in Fig. 3.

Type: INDIA, Maharashtra, Kolhapur district, Alate, Alamprabhu Sacred Grove, 788 m, N 1645'50.6", E 74²2'19.7", 17.09.2016, PR Lawand 077 (holo CAL!; iso SUK!, BSI!).

Prostrate shrubs. Stems trailing along ground, white to brown hispid, older semi-woody, c. $1 \mathrm{~cm}$ across, grooved, herbaceous towards apex, green, terete. Leaves simple, alternate; petioles 11-25 cm long, terete, densely white hirsute, longer than peduncles; lamina widely ovate to orbicular, 15$24 \times 12-25 \mathrm{~cm}$, apex acute, base cordate, basal lobes rounded, indumentum hirsute on adaxial surface, densely white sericeous on abaxial surface, secondary veins 8-9 pairs, conspicuous on abaxial surface. Cymes axillary, sub-capitate, 3-12flowered; peduncles 2-5 cm long, white hirsute, shorter than petioles (up to $3 / 4$ length). Flowers subsessile; bracts $2-3$, one large foliaceous, oblong, $2-3.5 \times 0.5-1.2 \mathrm{~cm}$, small bracts lance-ovate, $1-$ $2.5 \times 0.3-0.6 \mathrm{~cm}, 3$-nerved, hirsute on both surfaces, more densely on abaxial surface. Sepals 5 , unequal; outer 3 longer, $1.2-1.3 \times 0.4-0.5 \mathrm{~cm}$, apex acuminate; inner two $c .1 \times 0.4 \mathrm{~cm}$, narrowly oblong, apex acute, hirsute outside, glabrous inside, persistent, enlarge in fruiting. Corolla infundibuliform, rose-pink, 5-7 × 5-6 cm; throat purple, $c .1 \mathrm{~cm}$ wide, hirsute on mid-petaline bands outside; corolla lobes twisted in bud, lobes shallowly emarginate. Stamens 5, epipetalous, included within corolla tube, unequal, 2 longer 2-3 cm long, 3 shorter 1.5-2 cm long; filaments dilated and glandular hairy at base; anthers arrowshaped, 0.3-0.4 cm long, basifixed, pink. Ovary conical, 4-loculed, glabrous, encircled by annular disc; style single, 1.5-2 cm long; stigma biglobular, papillate, white. Berries rounded, 2-2.5 $\mathrm{cm}$ across, 1-4-seeded, glabrous, yellow when ripe. Seeds trigonal, white with visible hilum.

Flowering \& fruiting: Flowering from July to September and fruiting from October to December.

Habitat: This species grows in open habitats and trails amidst grassland but remain rooted near shrubs.

Etymology: The specific epithet 'sharadchandrajii' is chosen after Shri. Sharadchandraji Pawar, former Union Minister of Agriculture, Government of India, New Delhi for his valuable contribution to Indian agriculture.

Distribution: Known from a single locality (Fig. 4) in the sub-ranges of Sahyadris (the Western Ghats), India.

Specimens examined: INDIA, Maharashtra, Kolhapur district, Hatkanangale, Ramling hills, 


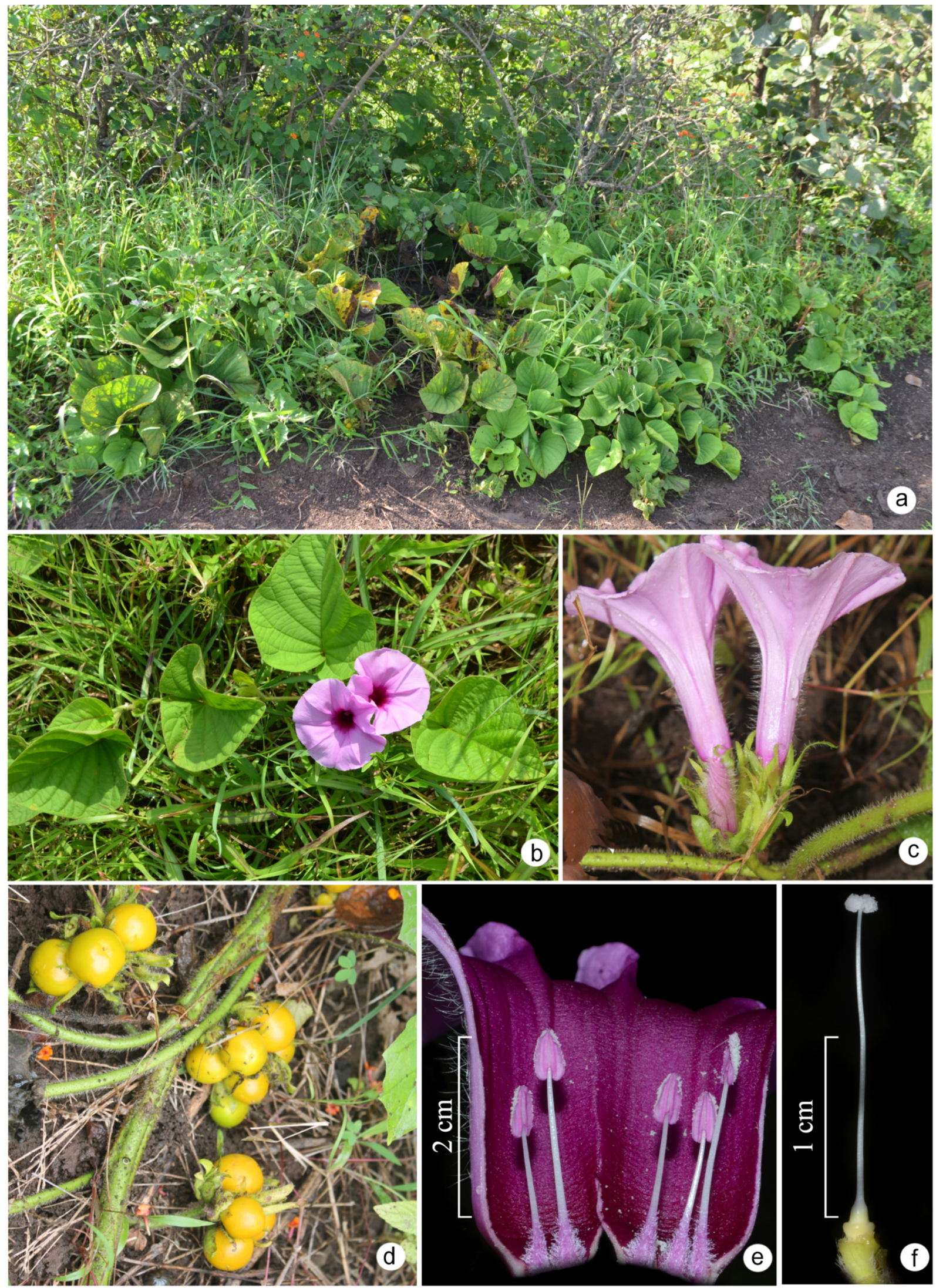

Fig. 1. Argyreia sharadchandrajii Lawand \& Shimpale: a. Habitat; b. Habit; c. Flower-side view; d. Fruiting habit; e. Androecium; f. Gynoecium (photos by Vinod Shimpale). 

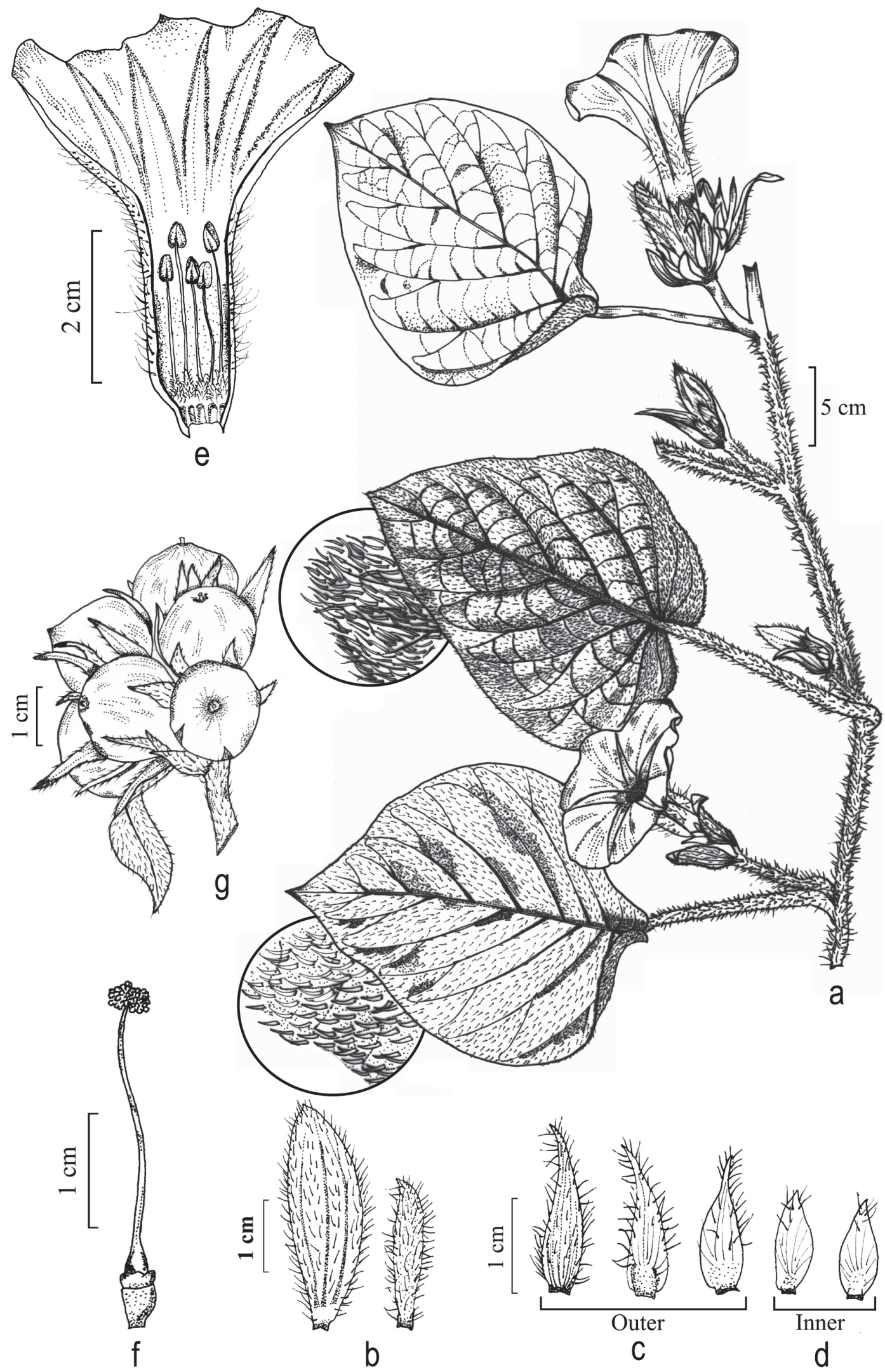

Fig. 2. Argyreia sharadchandrajii Lawand \& Shimpale: a. Flowering twig; b. Bracts; c. Outer Sepals; d. Inner sepals; e. Dissected corolla with androecium; f. Gynoecium with disc; g. Berries (from P.R. Lawand 077; drawn by Pramod Lawand). 

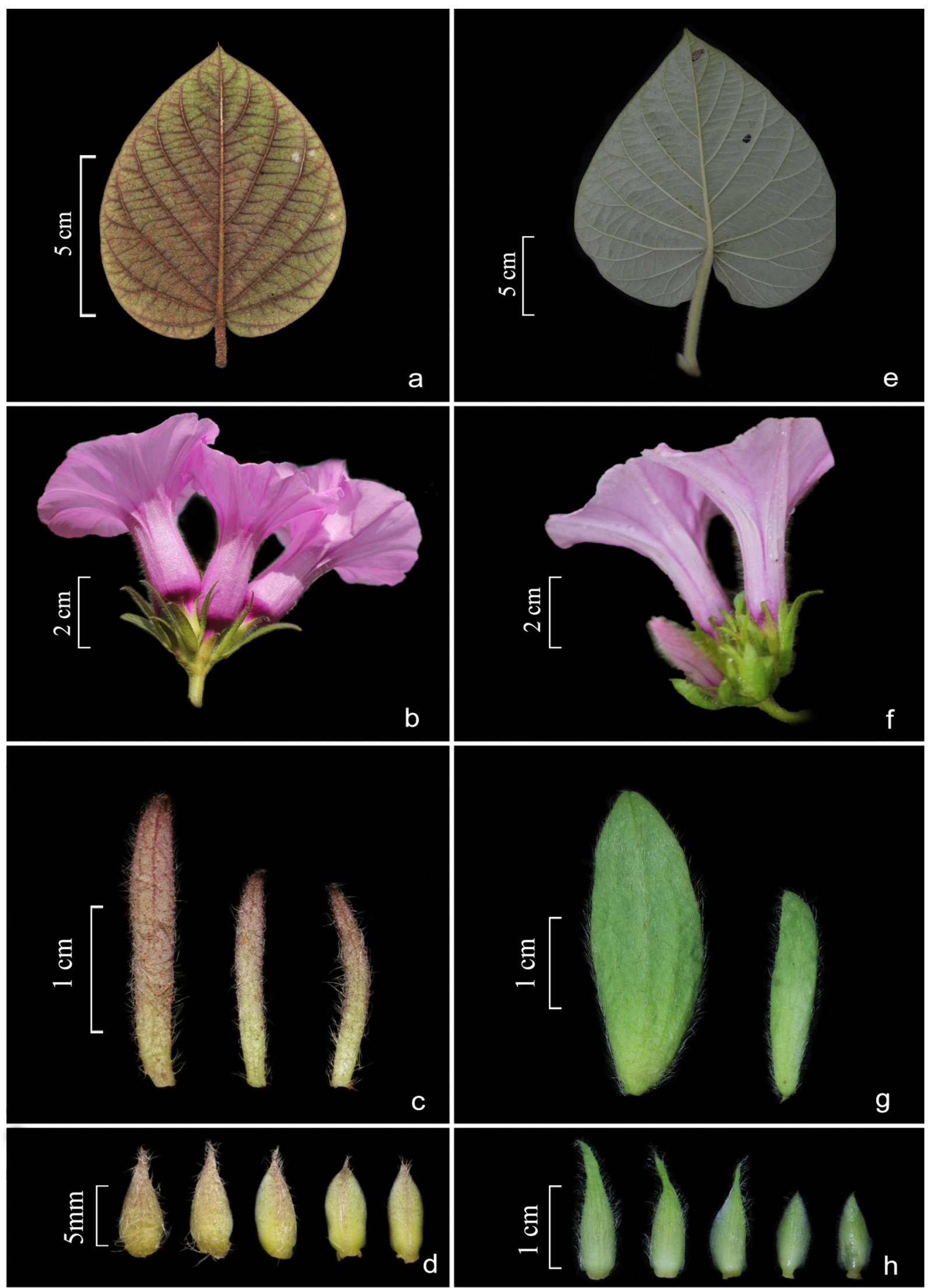

Fig. 3. Comparison between Argyreia pilosa Wight \& Arn. (a-d) and Argyreia sharadchandrajii Lawand \& Shimpale (e-h): a \& e. Abaxial leaf surface; b \& f. Inflorescence; c \& g. Bracts; d \& h. Sepals (photos by Pramod Lawand). 
Table 1. Morphological comparison between $A$. pilosa and $A$. sharadchandrajii

\begin{tabular}{|l|l|l|}
\hline Character & A. pilosa Wight \& Arn. & A. sharadchandrajii Lawand \& Shimpale \\
\hline Habit & Twining or initially prostrate & Always prostrate \\
\hline Leaves & $\begin{array}{l}\text { Ovate, } 11-16 \times 7-12 \mathrm{~cm}, \text { base shallowly cordate, } \\
\text { strigose on both surfaces }\end{array}$ & $\begin{array}{l}\text { Widely ovate or orbicular, } 15-24 \times 12-25 \mathrm{~cm}, \\
\text { base deeply cordate, hirsute adaxially, } \\
\text { white sericeous abaxially }\end{array}$ \\
\hline Petioles & Dorsally grooved & Dorsally not grooved \\
\hline Peduncles & Always more than half length of petiole & Always shorter than half length of petiole \\
\hline Bracts & $\begin{array}{l}\text { Linear, } 1.5-2.5 \times 0.2-0.4 \mathrm{~cm}, 1-\text { nerved, strigose } \\
\text { on both surfaces }\end{array}$ & $\begin{array}{l}\text { Oblong, 2-3.5 } \times 0.5-1.2 \mathrm{~cm}, 3-\text { nerved, hirsute } \\
\text { on both surfaces }\end{array}$ \\
\hline Sepals & $\begin{array}{l}\text { Sub-equal, outer three } 1-1.1 \mathrm{~cm} \text { long; } \\
\text { inner two c. } 0.9 \mathrm{~cm} \text { long }\end{array}$ & $\begin{array}{l}\text { Unequal, outer three } 1.2-1.3 \mathrm{~cm} \text { long, } \\
\text { inner two } c .1 \mathrm{~cm} \text { long }\end{array}$ \\
\hline Berries & $0.7-1.5 \mathrm{~cm}$ across & $2-2.5 \mathrm{~cm}$ across \\
\hline
\end{tabular}

13.08.2017, P.R. Lawand 078 (SUK); Ibid., $850 \mathrm{~m}$, 28.09.2018, P.R. Lawand 079 (SUK); Ibid., 03.10.2019, P.R. Lawand 089 (SUK).

Conservation status: At the type locality we could locate c. 100 mature individuals of this species occupying an area of $1.25 \mathrm{~km}^{2}$. In the presence of little data on the distribution range, an IUCN category, Data Deficient (DD) is assigned, according to IUCN Categories and Criteria (IUCN, 2019).

\section{Acknowledgements}

The authors are grateful to Prof. S.R. Yadav (Shivaji University, Kolhapur) for critical comments on the

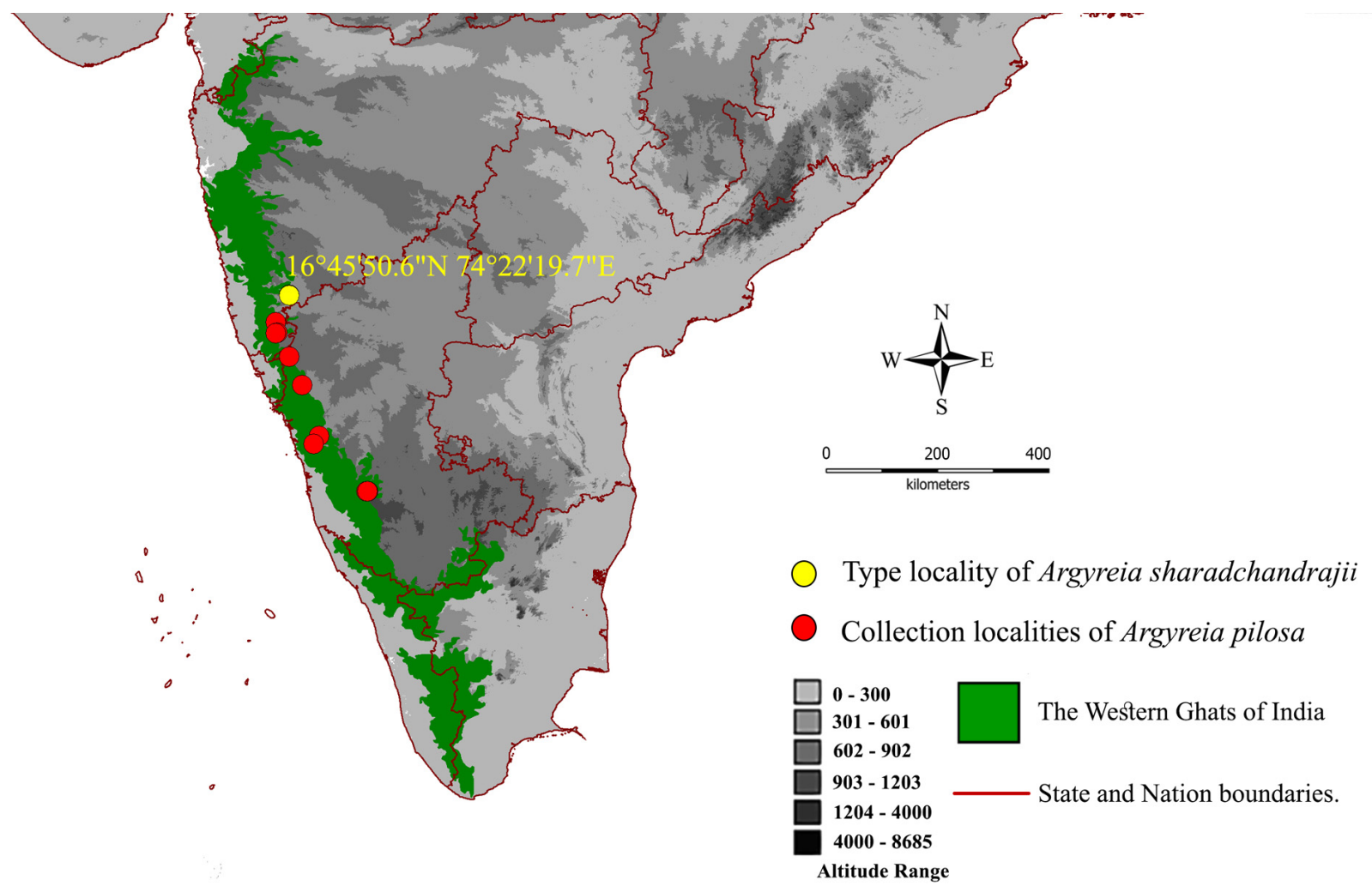

Fig. 4. Distribution map of Argyreia sharadchandrajii Lawand \& Shimpale and Argyreia pilosa Wight \& Arn. (map prepared in DIVA GIS, Hijmans et al., 2004). 
manuscript and Dr. V.M. Patil, Principal, The New College, Kolhapur for laboratory facilities. PRL is grateful to Council of Scientific and Industrial Research, New Delhi (CSIR file No. 08/631(0001)/ 2015-EMR-I) for fellowship.

\section{Literature Cited}

AUSTIN D.F. 1980. Convolvulaceae. In: DASSANAYAKE M.D. \& F.R. FOSBERG (eds.), A revised handbook of the flora of Ceylon, Volume I. CRC Press, New Delhi. pp. 288-363.

BALAKRISHNAN N.P. 1961. A new species of Argyreia from South India. Nelumbo 3(2): 163.

CHOISY J.D. 1834. Convolvulaceis orientalis. Memoires de la Société de physique et d'histoirenaturelle de Genève 6: 383-502.

CLARKE C.B. 1883. Convolvulaceae. In: HOOKER J.D. (ed.), The flora of British India. Volume 4. Reeve \& Co., London. pp. 179-228.

COOKE T. 1908. Flora of the Presidency of Bombay. Volume 2. Taylor \& Francis, London. https://doi.org/10.5962/ bhl.title. 10884

FANG R.C. \& G.W. STAPLES 1995. Convolvulaceae. In: WU C.Y. \& P.H. RAVEN (eds.), Flora of China, Volume 16. Science Press, Beijing, China. pp. 271-327.

HIJMANS R. J., GUARINO L., BUSSINK C., MATHUR P., CRUZ M., BARRENTES I. \& E. ROJAS. 2004. DIVA GIS. A geographic information system for the analysis of species distribution data. Available at: http:// www.diva gis.org.

IUCN 2019. Guidelines for Using the IUCN Red List Categories and Criteria. Version 14. Prepared by the Standards and Petitions Committee. Available at: http:/ /www.iucnredlist.org/documents/RedListGuidelines. pdf

KUMARI G.R., RAO P.S.N. \& G.V. SUBBARAO 2003. Flora of Visakhapatnam District, Andhra Pradesh. Botanical Survey of India, Coimbatore.

LAWAND P.R. 2019. Taxonomic revision of Argyreia Lour. (Convolvulaceae) from India. Ph.D. Thesis (unpublished), Shivaji University, Kolhapur.

LAWAND P.R., GAIKWAD S.V., GURAV R.V. \& V.B. SHIMPALE 2019. Karyomorphological studies in three species of Argyreia Lour. (Convolvulaceae) from India. The Nucleus 62(1): 71-75. https://doi.org/10.1007/ s13237-018-0252-9

MABBERLEY D.J. 2018. Mabberley's Plant-Book: a portable dictionary of plants, their classification and Uses. First South Asia edition. Cambridge University Press, Cambridge. https://doi.org/10.1017/9781316335581

MUÑOZ-RODRÍGUEZ P., CARRUTHERS T., WOOD J.R.I., WILLIAMS B.R.M., WEITEMIER K., KRONMILLER B., GOODWIN Z., SUMADIJAYA A., ANGLIN N.L., FILER D., HARRIS D., RAUSHER M.D., KELLY S., LISTON A. \& R.W. SCOTLAND 2019. A taxonomic monograph of Ipomoea integrated across phylogenetic scales. Nature Plants 5: 1136-1144. https://doi.org/10.1038/s41477-019-0535-4

ROXBURGH W. 1824. Flora Indica, or descriptions of Indian plants. Volume 2. The Mission Press, Serampore.

SAMPATHKUMAR R. \& R.K. AYYANGAR 1981. A critical appraisal of the karyophyletic taxonomy of Convolvulaceae. Journal of Cytology and Genetics 16: 89-99.

SANTAPAU H. \& V. PATEL 1958. Convolvulaceae of Bombay: additions and corrections. Transactions of Bose Research Institute 22: 33-42.

SHALINI S., SUJANA K.A., ARISDASON W. \& D. MAITY. 2020. A new species of Argyreia (Convolvulaceae) from the southern Western Ghats, Tamil Nadu, India. Rheedea 30(4): 444-449. https:// dx.doi.org/10.22244/rheedea.2020.30.4.03

STAPLES G.W. \& P. TRAIPERM 2010. Argyreia Lour. In: SANTISUK, T. \& K. LARSEN (eds.). Flora of Thailand, Volume 10(3). Royal Forest Department, Prachachon, Bangkok. pp. 337-371.

STAPLES G.W. \& P. TRAIPERM 2017. A nomenclatural review of Argrreia (Convolvulaceae). Taxon 66(2): 445477. https://doi.org/10.12705/662.12

OOSTSTROOM S.J. VAN 1943. The Convolvulaceae of Malaysia IV. Blumea 5(2): 339-340.

OOSTSTROOM S.J. VAN \& R.D. HOOGLAND 1953. Convolvulaceae. In: VAN STEENIS C.G.G.J. (ed.) 1948-1954. Flora Malesiana, Series I, Volume IV. Noordhoff-Kolff, Djakarta. pp. 388-512. https://doi.org/ 10.5962/bhl.title.40744 